\title{
The differential carbon-fixing and nitrogen-assimilating enzyme activities of Oscillatorian marine cyanobacterium Phormidium valderianum BDU 20041
}

\author{
G. DINESHBABU ${ }^{* * * *}$, V.S. UMA ${ }^{* * * *}$, M. SHYLAJANACIYAR*, V. RASHMI*,*, D. PRABAHARAN*, \\ and L. UMA* ${ }^{*+}$ \\ National Facility for Marine Cyanobacteria, Department of Marine Biotechnology, School of Marine Sciences, \\ Bharathidasan University, 620024 Tiruchirappalli, Tamil Nadu, India* \\ Bioprocess Development Laboratory, Department of Biosciences and Bioengineering, Indian Institute of Technology \\ Guwahati, Guwahati, Assam, India** \\ Environmental Safety Division, Indira Gandhi Centre for Atomic Research, Kalpakkam, Tamil Nadu, India*** \\ Department of Microbiology, Srimad Andavan College of Arts and Science, Tiruchirappalli, Tamil Nadu, India ${ }^{\#}$
}

\begin{abstract}
We have identified an efficient filamentous marine cyanobacterium, Phormidium valderianum BDU 20041, which was adaptive to different concentrations of $\mathrm{CO}_{2}$. In our study, $P$. valderianum BDU 20041 was grown under ambient $(0.04)$ and elevated $(2,3,4,5,10$, and $15 \%) \mathrm{CO}_{2}$ concentration. Its optimal growth occurred at $3 \% \mathrm{CO}_{2}$ supply. P. valderianum displayed similar carbon fixation activities through Rubisco, phosphoenolpyruvate carboxylase (PEPC), carbonic anhydrase, and malate dehydrogenase. The activity of Rubisco, the primary carbon-fixing enzyme, was found to be approximately $80 \%$ higher in $P$. valderianum grown under $4 \% \mathrm{CO}_{2}$ than under ambient air. This was substantiated by Western blot. The nitrogen-assimilating enzymes shared a similar trend at higher $\mathrm{CO}_{2}$ concentrations. Our study is one of the few reports that examined the activities of $\mathrm{CO}_{2}$-fixing and nitrogen-assimilating enzymes together. Due to the active PEPC, this cyanobacterium was found to have active $\mathrm{C}_{3}$ and $\mathrm{C}_{4}$ enzymes that promoted higher $\mathrm{CO}_{2}$ fixation and cellular growth. Thus, it may be an efficient organism for biotechnological exploitation.
\end{abstract}

Additional key words: biomass productivity; elevated $\mathrm{CO}_{2}$ concentration; nitrate reductase; nitrite reductase.

\section{Introduction}

Atmospheric $\mathrm{CO}_{2}$ concentrations were 408.71 ppm in July 2018 and are increasing at a steady rate (NOAA 2018). At this rate, environmental experts believe that the concentrations will reach $500 \mathrm{ppm}$ or higher by the end of the century (Kranz et al. 2010). Reports on effects of enhanced $\mathrm{CO}_{2}$ concentration on the growth, lipid content, and fatty acid profile of microalgae are numerous. The microalgal response to elevated $\mathrm{CO}_{2}$ concentrations depends extensively on the type of species. There are studies that have recorded increased growth of the cyanobacterial species at elevated $\mathrm{CO}_{2}$ concentrations; while in contrast, some species were even inhibited by increased $\mathrm{CO}_{2}$ concentrations (de Morais and Costa 2007, Chiu et al. 2008). Therefore, it is not possible to predict the long-term effects of elevated $\mathrm{CO}_{2}$ on microalgal growth without improving the understanding of underlying mechanisms responsible for photosynthetic acclimation. For example, enzymatic activities that induce photosynthetic adaptation during microalgal growth in elevated $\mathrm{CO}_{2}$ are poorly understood. However, there are very few studies on the effect of elevated $\mathrm{CO}_{2}$ concentration on carbon-fixing enzymes and its implications for fixation (Jouanneau and Tabita 1987, Hayashi et al. 1995).

Variations in $\mathrm{CO}_{2}$ concentrations supplied to cultures can affect amendments in cellular carbon acquisition pathways and elemental ratios, which are mostly species-specific (Raven 1997, Tortell et al. 2000, Burkhardt et al. 2001, Fu et al. 2007, Hutchins et al. 2007). Most of the studies on this topic have mainly focused on the activity of a single enzyme and its growth at elevated $\mathrm{CO}_{2}$ concentrations. Ribulose-1,5-bisphosphate carboxylase/oxygenase (Rubisco, EC 4.1.1.39) is the primary enzyme in the Calvin-Benson cycle $\left(\mathrm{C}_{3}\right.$ cycle), while phosphoenolpyruvate carboxylase (PEPC, EC 4.1.1.31) is a chief enzyme in carbon fixation in the $\mathrm{C}_{4}$ cycle. Carbonic anhydrase, a zinc metalloenzyme (CA, EC 4.2.1.1), catalyzes the reversible dehydration of $\mathrm{HCO}_{3}{ }^{-}$to $\mathrm{CO}_{2}$. As Rubisco is a rate-limiting enzyme at lower carbon concentrations that

Received 5 May 2018, accepted 29 November 2018.

${ }^{+}$Corresponding author; phone: +919442107584, fax: +91-431-2407084, e-mail: uma@bdu.ac.in

Abbreviations: CA - carbonic anhydrase; Chl - chlorophyll; $C_{\mathrm{i}}$ - intracellular $\mathrm{CO}_{2}$ concentration; GS - glutamine synthetase; $\mathrm{MDH}$ - malate dehydrogenase; NIR - nitrite reductase; NR - nitrate reductase; PEPC - phosphoenolpyruvate carboxylase.

Acknowledgements: The authors thank the Department of Science and Technology (Govt. of India) for their financial support (Grant No. DST/IS-STAC/CO2-SR-43/09). The authors also thank the Department of Biotechnology (Govt. of India) for funding National Facility for Marine Cyanobacteria (Grant No. BT/IS/MAIN/1/98).and the Bioinformatics Centre (Grant No. BT/BI/04/038/98). 
accumulates carbon in carboxysomes of cyanobacteria, the functioning of carbonic anhydrase is crucial. Malate dehydrogenase (MDH, EC 1.1.1.37) catalyzes the interconversion of malate and oxaloacetate with $\mathrm{NAD}^{+}$or NADH as coenzymes, which also play a role in carbon metabolism. In a non-sulfur photosynthetic bacterium, Rhodobacter sphaeroides, Rubisco biosynthesis was repressed, and its activities were inhibited at high concentrations of $\mathrm{CO}_{2}(6 \%)$ (Jouanneau and Tabita 1987); in contrast, in the thermophilic cyanobacterium, Chroococcidiopsis sp. strain TS-821, the enzyme activity was enhanced in response to higher $\mathrm{CO}_{2}$ concentrations (5 and 10\%) (Hayashi et al. 1995).

In addition to carbon fixation, it has been suspected that increased $\mathrm{CO}_{2}$ availability may potentially reduce the energy or nutrients needed for carbon acquisition (Hutchins et al. 2007). Reports on Trichodesmium sp. have shown that externally supplied $\mathrm{CO}_{2}$ has a role in determining the nitrogen- and carbon-fixing rates (Barcelos e Ramos et al. 2007, Hutchins et al. 2007, Levitan et al. 2007).

This study aimed to assess the $\mathrm{CO}_{2}$ fixation and nitrogen assimilation of enzymes at different $\mathrm{CO}_{2}$ concentrations. The four major enzymes involved in $\mathrm{CO}_{2}$ fixation, Rubisco, $\mathrm{PEPC}, \mathrm{CA}, \mathrm{MDH}$, and three nitrogen-assimilating enzymes, nitrate reductase (NR, EC 1.7.99.4), nitrite reductase (NIR, EC 1.7.2.1), and glutamine synthetase (GS, EC 6.3.1.2), were investigated in the Oscillatorian filamentous non-heterocystous cyanobacterium P. valderianum BDU 20041. This organism was screened out of 18 selected organisms (data not shown) and was validated through radiometric, electrometric, and colorimetric assays. The expression of Rubisco at various $\mathrm{CO}_{2}$ concentrations was also confirmed by an immunoblot technique.

\section{Materials and methods}

Cyanobacterial strain and culture conditions: The cyanobacterial strain used in this study is a non-heterocystous, filamentous organism, named Phormidium valderianum BDU 20041, which was acquired from the germplasm of the National Facility for Marine Cyanobacteria, Bharathidasan University, Tiruchirappalli, India. The organism was grown and conserved in ASN III (artificial sea nutrient) medium (Rippka et al. 1979) in a controlled culture room at $25 \pm 2{ }^{\circ} \mathrm{C}$ with continuous aeration and illumination with white fluorescent light of an intensity of $20 \mu \mathrm{mol}$ (photon) $\mathrm{m}^{-2} \mathrm{~s}^{-1}$.

Cyanobacterial growth with continuous $\mathrm{CO}_{2}$ : An initial inoculum equivalent to $0.1 \mathrm{~g} \mathrm{~L}^{-1}$ (dry mass) of $P$. valderianum BDU 20041 culture at the mid-log phase was inoculated into ASN III medium. The media containing the cultures were continuously bubbled with different concentrations of $\mathrm{CO}_{2}$, i.e., $2,3,4,5,10$, and $15 \%$ at 0.1 vvm flow rate using a $99.9 \%$ pure $\mathrm{CO}_{2}$ cylinder (Bhuruka Gases, Bangalore, India) aided with an aerator for $24 \mathrm{~h}$ with a continuous light intensity of $20 \mu \mathrm{mol}$ (photon) $\mathrm{m}^{-2} \mathrm{~s}^{-1}$. The temperature was maintained at $25 \pm 2{ }^{\circ} \mathrm{C}$. The organism in ASN III medium aerated with $\sim 0.04 \% \mathrm{CO}_{2}$ (ambient air) served as the control. Unbuffered medium was used for all the experiments. Triplicate values of chlorophyll (Chl) and dry mass were recorded, averaged, and plotted with standard deviations.

Preparation of cell extract: Mid log-grown cultures were harvested after 12 and $24 \mathrm{~h}$ by centrifugation at $5,000 \times \mathrm{g}$, and the pellets were washed twice with Tris- $\mathrm{HCl}$ buffer ( $\mathrm{pH}$ 7.8). Cold mortar, pestle, and glass powder were used to homogenize the cyanobacterial pellets. The cellular debris and other unwanted components were removed by centrifuging the homogenate at $20,000 \times g$ for $30 \mathrm{~min}$. The supernatant was withdrawn and spun again for further purification. The resultant blue-colored supernatant was used as the crude enzyme extract, and the protein concentration was determined according to Lowry et al. (1951).

\section{Enzyme assays: carbon-fixing enzymes}

Rubisco: The carboxylase activity of the Rubisco enzyme was radiometrically analyzed following the method of Perchorowicz et al. (1981) with some modifications. The assay mixture consisted of $2.19 \mathrm{mM}$ ribulose-1,5bis-phosphate, $0.898 \mathrm{mM} \mathrm{NaHCO} 3$ with $46.9 \mathrm{kBq}$ of ${ }^{14} \mathrm{C}$ radioactivity and $10 \mathrm{mM} \mathrm{MgCl}_{2}$. We added $25 \mu \mathrm{l}$ of assay mixture to $50 \mu \mathrm{l}$ of the extract, and the mixture was incubated for $5 \mathrm{~min}$. The reaction was terminated by adding $400 \mu \mathrm{l}$ of $25 \%$ trichloroacetic acid (TCA). TCA removes any unbound radiolabelled carbon and the ${ }^{14} \mathrm{C}$ radioactivity incorporated in the acid-stable end products were measured in a liquid scintillation counter (Ramona Star, Elysisa Raytest, Germany). The rate of end product formation was determined from the rate of ${ }^{14} \mathrm{C}$ incorporation and expressed as $\mu$ moles of $\mathrm{CO}_{2}$ fixed per $\mathrm{mg}$ of protein. From the specific activity of $\mathrm{NaH}^{14} \mathrm{CO}_{3}$ the amount of $\mathrm{CO}_{2}$ fixed is determined.

PEPC: The radiometric assay of PEPC activity was performed as defined by Owttrim and Colman (1986) with some variations. The standard assay mixture consisted of $50 \mathrm{mM}$ TES buffer at $\mathrm{pH} 7.5,5 \mathrm{mM} \mathrm{MgCl}_{2}$, $2.5 \mathrm{mM}$ phosphoenolpyruvate (PEP), $25 \mathrm{mM} \mathrm{NaH}{ }^{14} \mathrm{CO}_{3}$ (specific activity, $1.8 \mathrm{MBq} \mathrm{mmol}^{-1}$ ) and $25 \mu \mathrm{l}$ of the crude enzyme. Background radiations were nullified with a blank solution. The assay mixtures without PEP were incubated at $30^{\circ} \mathrm{C}$ for $10 \mathrm{~min}$. The reaction components were mixed with PEP, and after $10 \mathrm{~min}, 0.1 \mathrm{ml}$ of $25 \%$ trichloroacetic acid was added to stop the reaction. The radioactivity incorporated was measured using a radiospectrophotometer (Raytest Isotopenmessgeraete, Germany). The rate of PEPC-mediated oxaloacetate formation per $\mathrm{mg}$ of the protein was calculated from the rate of ${ }^{14} \mathrm{C}$ incorporation, considering the specific activity of the added $\mathrm{NaH}^{14} \mathrm{CO}^{3}$, and the absolute amount of dissolved inorganic carbon in the assay mixture was determined.

Carbonic anhydrase: The electrometric method of Wilbur and Anderson (1948) was used to assay the activity of carbonic anhydrase. Four $\mathrm{ml}$ of ice-cold $\mathrm{CO}_{2}$-saturated water was added to the reaction mixture of $0.2 \mathrm{M}$ Tris- $\mathrm{HCl}$ buffer, $\mathrm{pH} 8.0$, and $0.1 \mathrm{ml}$ of the freshly diluted enzyme. 
The time required for the $\mathrm{pH}$ to drop from 8.3 to 6.3 was recorded. A unit of enzyme is defined as $[2 \times(\mathrm{T} 0-\mathrm{T})] / \mathrm{T}$, where $\mathrm{T}$ is time taken with enzyme and $\mathrm{T} 0$ is without enzyme. Enzyme units is calcualted by $2 \times(\mathrm{T} 0-\mathrm{T}) /(\mathrm{T} \times$ $\mathrm{mg}$ of protein in reaction mix).

Malate dehydrogenase: The activity was assayed following Baker and Bramhall (1972) and the assay mixture consisted of $6 \mathrm{mM}$ oxaloacetic acid and $3.7 \mathrm{mM}$ of NADH in $0.1 \mathrm{M}$ potassium phosphate buffer at $\mathrm{pH} 7.4$. On addition of the enzyme, decrease in $\Delta \mathrm{A}_{340}$ was recorded for 3-5 min. Enzyme units per $\mathrm{mg}$ of protein calcualted by $\Delta_{340} /$ $[6.22 \times \mathrm{mg}$ (protein) in $\mathrm{ml}$ of reaction $\mathrm{mix}]$.

\section{Enzyme assays: nitrogen-assimilating enzymes}

Nitrate and nitrite reductase: The assay of nitrate reductase and nitrite reductase activity was based on the reduction of nitrate and nitrite, which utilize sodium dithionite-reduced methyl viologen as the electron donor (Herrero and Guerrero 1986). The reaction product, diazotized sulphanilamide, further reacts with N-(1-naphthyl) ethylenediamine dihydrochloride and forms a red dye. The absorbance was read at $540 \mathrm{~nm}$ (Cary 100 bio UV-VIS spectrophotometer, Varian, USA) and the activity was expressed as the $\mu \mathrm{g}$ (nitrite formed) (for NR) or removed (for NIR) $\mathrm{g}^{-1}$ (dry mass) $\mathrm{min}^{-1}$.

Glutamine synthetase activity was estimated in the washed cyanobacterial pellet permeabilized by toluene at $4^{\circ} \mathrm{C}$. The activity was calculated in vitro by incubating the supernatant with $1 \mathrm{ml}$ of reaction mixture for $30 \mathrm{~min}$ in the dark at $37^{\circ} \mathrm{C}$ (Shapiro and Stadtman 1970). At the end of the reaction, the $\mathrm{A}_{540}$ was measured (Cary 100 bio UV-VIS spectrophotometer, Varian, USA), and the activity was expressed as $\mu \mathrm{g}\left(\gamma\right.$-glutamyl hydroxamate formed) $\mathrm{g}^{-1}$ (dry mass) $\min ^{-1}$.

Western blotting for Rubisco: Proteins separated using $12 \%$ SDS-PAGE were transferred onto a nitrocellulose membrane at $12 \mathrm{~V}$ for $1 \mathrm{~h}$ using a semi-dry Western blotting system (Bio-Rad, Hercules, CA, USA). Skimmed milk powder $(3 \%, \mathrm{w} / \mathrm{v})$ in Tris-buffered saline with $0.1 \%$ Tween-20 (TBS-T) was used to block the membrane for an hour. After three washes with TBS-T for $5 \mathrm{~min}$ each, the membrane was incubated with polyclonal anti-Rubisco antibody produced in chicken (Sigma, St. Louis, MO) at a dilution of $1: 1,500$ overnight at $4^{\circ} \mathrm{C}$. After washing, the membrane was incubated for $1 \mathrm{~h}$ with anti-chicken immunoglobulin $\mathrm{G}$ (IgG) peroxidase-coated antibody (Sigma, St. Louis, MO) at a dilution of 1:10,000. After another wash, the blots in the membrane were developed by the addition of 4-chloro-naphthol (Sigma, St. Louis, $\mathrm{MO}$ ) and $30 \% \mathrm{H}_{2} \mathrm{O}_{2}$ substrate solution. The developed membrane was scanned using BioRAD Gel Doc EZ imager and the scanned image was processed with Image Lab Software 6.0 (BioRad Laboratories, USA).

Statistical analysis: Various data obtained in the study were statistically analysed by Tukey's HSD test $(p<0.05)$ in Matlab 16 and plotted in Microsoft Excel and Origin.

\section{Results}

Growth of $P$. valderianum BDU 20041 at different $\mathrm{CO}_{2}$ concentrations, i.e., 0.04 (ambient air), 2, 3, 4, 5, 10, and $15 \%$, was calculated in terms of Chl $a$ (Fig. 1). However, the cultures were capable of tolerating the continuous flow of all the tested $\mathrm{CO}_{2}$ concentrations; specifically, $3 \% \mathrm{CO}_{2}$ was found to yield increased growth compare to other tested concentrations. This concentration reflected a higher specific growth rate $\left(0.226 \pm 0.007 \mu \mathrm{g} \mathrm{d}^{-1}\right)$ and biomass productivity $\left(83 \pm 3.98 \mathrm{mg} \mathrm{L}^{-1} \mathrm{~d}^{-1}\right)$ at $3 \% \mathrm{CO}_{2}$ (Table 1).

Effect of $\mathrm{CO}_{2}$ on Rubisco activity and content: The Rubisco activity of $P$. valderianum BDU 20041 harvested after 12 and $24 \mathrm{~h}$ at different $\mathrm{CO}_{2}$ concentrations is shown in Fig. 2A. The organism subjected to 3 and $4 \% \mathrm{CO}_{2}$ showed higher Rubisco activity. After $12 \mathrm{~h}$, the enzyme activities of the cultures grown with different $\mathrm{CO}_{2}$ concentrations increased with an increase in the $\mathrm{CO}_{2}$ concentration, reaching maximum activity at $15 \% \mathrm{CO}_{2}$. The activity of $15 \% \mathrm{CO}_{2}$-grown cells was $2.26 \mu \mathrm{mol}\left(\right.$ fixed $\mathrm{CO}_{2}$ ) $\mathrm{min}^{-1} \mathrm{mg}^{-1}$ (protein), which was more than double of that under ambient air-grown cultures. The enzyme activity after $24 \mathrm{~h}$ of growing with $2-5 \% \mathrm{CO}_{2}$ was higher than that under the ambient air by $47.4,75.5,80.6$, and $54.1 \%$, respectively. The maximum activity recorded at $4 \% \mathrm{CO}_{2}$ was $3.54 \mu \mathrm{mol}\left(\mathrm{CO}_{2}\right.$ fixed $) \mathrm{min}^{-1} \mathrm{mg}^{-1}$ (protein). The activity at a higher $\mathrm{CO}_{2}$ concentration was inversely proportional (Fig. 2A).

The increased activity of Rubisco after $12 \mathrm{~h}$ with the increased $\mathrm{CO}_{2}$ showed that the activity was $\mathrm{CO}_{2}$-concentration dependent. To substantiate the above finding, the protein extract of $P$. valderianum BDU 20041 grown in various $\mathrm{CO}_{2}$ concentrations for $12 \mathrm{~h}$ was analysed by immunoblotting for Rubisco. The Western blot of Rubisco corroborated the results of the radiometric assay.

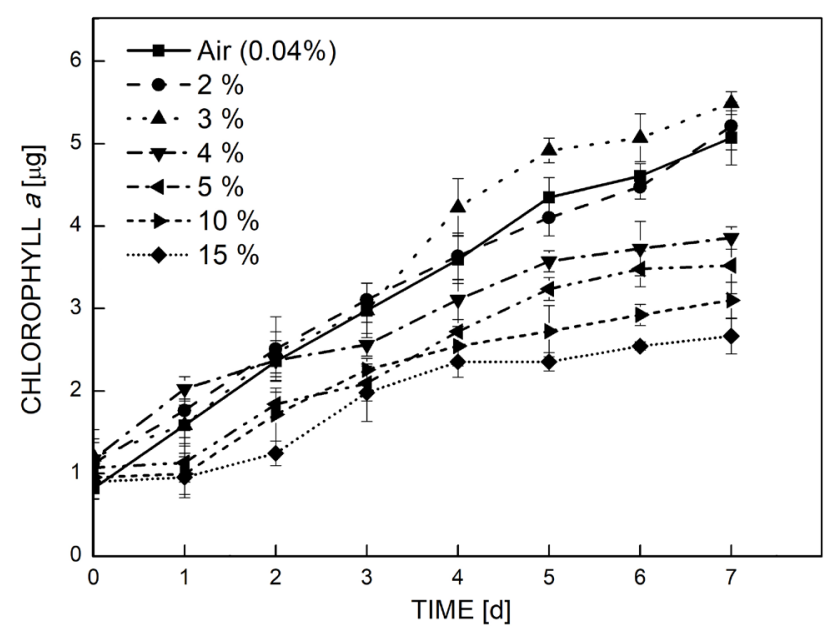

Fig. 1. Effect of the concentration of $\mathrm{CO}_{2}$ aeration on the growth (expressed as Chl $a$ content) of Phormidium valderianum BDU 20041. In the cultures, $1.0 \mathrm{~g}$ of algal cells were inoculated and cultivated under continuous supply of ambient air, 2, 3, 4, 5, 10, and $15 \% \mathrm{CO}_{2}$. Values are means $\pm \mathrm{SD}(n=3)$. 
Table 1. Growth performance of Phormidium valderianum BDU 20041 sparged with different concentrations of continuous $\mathrm{CO}_{2}$ for seven days. Values (mean $\pm \mathrm{SD}, n=3$ ) with the same letters are not significantly different according to Tukey's HSD test $(p<0.05)$.

\begin{tabular}{lllc}
\hline $\mathrm{CO}_{2}[\%]$ & Biomass productivity $\left[\mathrm{mg} \mathrm{L}^{-1} \mathrm{~d}^{-1}\right]$ & Specific growth rate $[\mu ?] \mathrm{CO}_{2}$ fixation rate $\left[\mathrm{mg}(\mathrm{C}) \mathrm{L}^{-1} \mathrm{~d}^{-1}\right]$ \\
\hline 0.04 & $66.66 \pm 3.45^{\mathrm{C}}$ & $0.183 \pm 0.002^{\mathrm{C}}$ & $122.21 \pm 4.08^{\mathrm{C}}$ \\
2 & $72.13 \pm 3.12^{\mathrm{B}}$ & $0.198 \pm 0.003^{\mathrm{B}}$ & $126.57 \pm 5.17^{\mathrm{B}}$ \\
3 & $83.33 \pm 3.98^{\mathrm{A}}$ & $0.221 \pm 0.007^{\mathrm{A}}$ & $152.77 \pm 6.74^{\mathrm{A}}$ \\
4 & $65.00 \pm 3.59^{\mathrm{C}}$ & $0.176 \pm 0.004^{\mathrm{C}, \mathrm{D}}$ & $122.24 \pm 5.32^{\mathrm{C}}$ \\
5 & $61.33 \pm 1.08^{\mathrm{D}}$ & $0.170 \pm 0.005^{\mathrm{C}, \mathrm{D}}$ & $112.43 \pm 3.70^{\mathrm{D}}$ \\
10 & $50.33 \pm 2.56^{\mathrm{E}}$ & $0.163 \pm 0.004^{\mathrm{D}}$ & $92.27 \pm 4.24^{\mathrm{E}}$ \\
15 & $51.00 \pm 1.87^{\mathrm{E}}$ & $0.169 \pm 0.001^{\mathrm{D}}$ & $93.5 ? \pm 3.55^{\mathrm{E}}$ \\
\hline
\end{tabular}

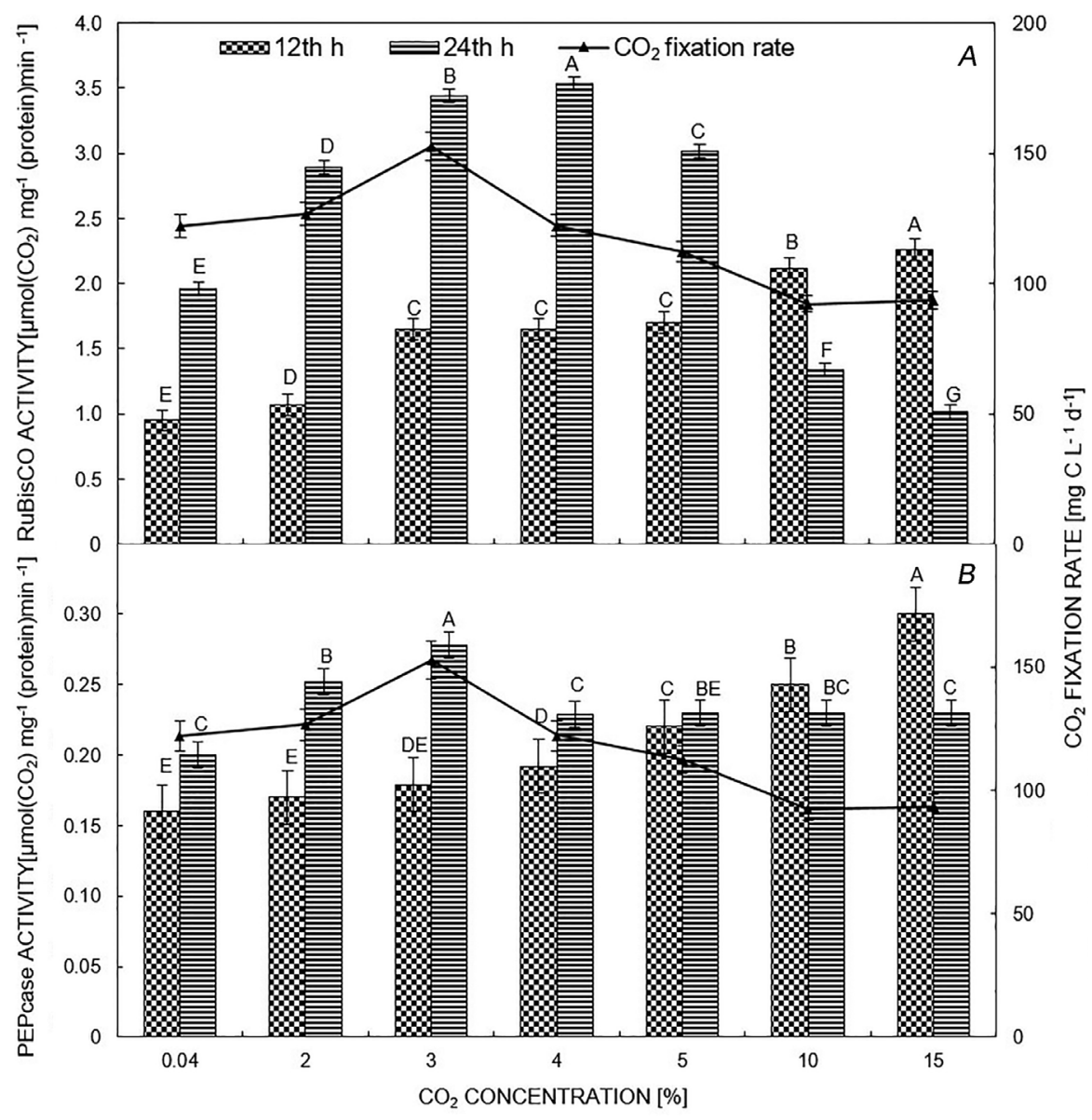

Fig. 2. Activity of ribulose-1,5-bisphosphate carboxylase/oxygenase (Rubisco) $(A)$ and phosphoenolpyruvate carboxylase (PEPC) $(B)$ of Phormidium valderianum BDU 20041 during growth in continuous aeration of ambient air and elevated $\mathrm{CO}_{2}$, recorded at 12 and $24 \mathrm{~h}$. In order to determine the correlation between the $\mathrm{CO}_{2}$ assimilation rate and enzyme activities, the $\mathrm{CO}_{2}$ fixation rate of the organism grown at different $\mathrm{CO}_{2}$ concentration is plotted on the secondary $y$-axis. Values are means $\pm \mathrm{SD}$ $(n=3)$. Different capital letters indicate a significant difference by Tukey's test $(p<0.05)$.
Western blot of $P$. valderianum BDU 20041 showed that the Rubisco content was higher with increasing $\mathrm{CO}_{2}$ concentrations (Fig. 3). The Rubisco content was almost four and ten times higher than that of ambient air-grown cultures. The 24-h incubated cultures did not show much deviation in their content, and the $3 \% \mathrm{CO}_{2}$-grown cultures revealed a slightly more intense band, indicating higher Rubisco content. The cultures grown at the $\mathrm{CO}_{2}$ concentration above $3 \%$ (i.e., 4, 5, 10, and 15\%) showed the reduced Rubisco content compared to the ambient air-grown cultures (Fig. 3). Interestingly, after $24 \mathrm{~h}$, the activity decreased in cultures grown at $\mathrm{CO}_{2}$ above $3 \%$, while the Rubisco content remained the same in all the concentrations.
Effect of $\mathrm{CO}_{2}$ on PEPC activity: PEPC, the principal $\mathrm{C}_{4}$ carbon fixation enzyme, showed a pattern similar to the Rubisco activity at the tested $\mathrm{CO}_{2}$ concentrations. After $12 \mathrm{~h}$, a maximal activity of $0.3 \mu \mathrm{mol}\left(\mathrm{CO}_{2}\right.$ fixed $) \mathrm{min}^{-1}$ $\mathrm{mg}^{-1}$ (protein) was observed in the $15 \% \mathrm{CO}_{2}$ cultures, whereas after $24 \mathrm{~h}$, the activity decreased in cultures with $\mathrm{CO}_{2}>3 \%$, similar to the pattern observed with the Rubisco activity. The maximum activity of the enzyme $\left[0.2708 \mu \mathrm{mol}\left(\mathrm{CO}_{2}\right.\right.$ fixed) $\mathrm{min}^{-1} \mathrm{mg}^{-1}$ (protein) $]$ after $24 \mathrm{~h}$ was observed at the $3 \% \mathrm{CO}_{2}$ concentration (Fig. $2 B$ ).

The carbon-fixation rate was reflected in the growth of $P$. valderianum BDU 20041 with different elevated $\mathrm{CO}_{2}$ concentrations. The amounts and activities of $\mathrm{Ru}-$ bisco and PEPC under given environmental conditions are 


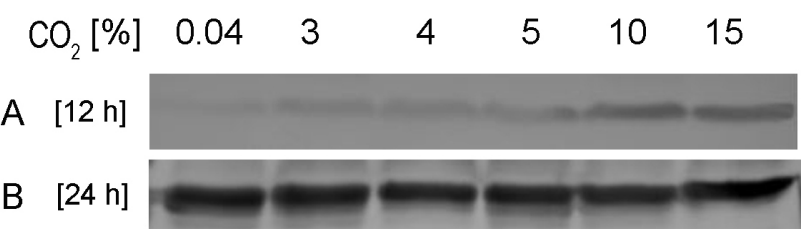

Fig. 3. Western blot analysis for ribulose-1,5-bisphosphate carboxylase/oxygenase (Rubisco) of Phormidium valderianum BDU 20041 grown in ambient air and elevated $\mathrm{CO}_{2}$ concentration for $12(A)$ and $24 \mathrm{~h}(B)$. The blots were developed by specific monoclonal antibodies against Rubisco and developed using secondary antibody linked with horse radish peroxidase and 4-chloronaphthol.

important factors in the regulation of $\mathrm{CO}_{2}$ assimilation. Hence, it is worthwhile to infer the relationship between the carbon fixation rate and the recorded activities of the carbon-fixing enzymes. The $\mathrm{CO}_{2}$-fixation rate stoutly correlated with the activities of Rubisco and PEPC. In $P$. valderianum $\mathrm{BDU}$ 20041, the $\mathrm{CO}_{2}$-fixation rate increased with $\mathrm{CO}_{2}$ concentration up to $3 \%$ together with the enzyme activities, even after $24 \mathrm{~h}$ (Fig. 2).

Effect of $\mathrm{CO}_{2}$ on $\mathrm{CA}$ and $\mathrm{MDH}$ : The CA activity was reflected in the cultures flushed with different $\mathrm{CO}_{2}$ concentrations; it showed an increasing activity with enhanced $\mathrm{CO}_{2}$ concentrations after $12 \mathrm{~h}$. P. valderianum BDU 20041 cultures grown with $15 \% \mathrm{CO}_{2}$ showed a maximum activity of $14.11 \mathrm{U} \mathrm{mg}^{-1}$ (protein) after $12 \mathrm{~h}$. Nevertheless, unlike Rubisco $\left(\mathrm{C}_{3}\right)$ and PEPC $\left(\mathrm{C}_{4}\right)$, the CA activity did not show any difference after $24 \mathrm{~h}$. The activity remained almost similar at all the $\mathrm{CO}_{2}$ concentrations tested (Fig. 4A). As in the other three enzymes, MDH activity also increased with the increasing $\mathrm{CO}_{2}$ concentration after $12 \mathrm{~h}$. Interestingly, the maximum activity of MDH was found at $5 \%$ after $24 \mathrm{~h}\left(0.25 \mathrm{U} \mathrm{mg}^{-1}\right.$ (protein) (Fig. $\left.4 B\right)$.

Nitrogen-assimilating enzymes at elevated $\mathrm{CO}_{2}$ : The nitrogen-assimilating enzymes, NR, NIR, and GS of $P$. valderianum BDU 20041, were assayed for their activity after 12 and $24 \mathrm{~h}$ of the exposure to the enhanced $\mathrm{CO}_{2}$ concentrations of 3 and $15 \%$. The activities of all three nitrogen-assimilating enzymes, in samples grown with $3 \%$ $\mathrm{CO}_{2}$, showed higher activities than that under the ambient air and $15 \% \mathrm{CO}_{2}$ after both 12 and $24 \mathrm{~h}$. Irrespective of the cellular demand, the assimilation of nitrogen was very

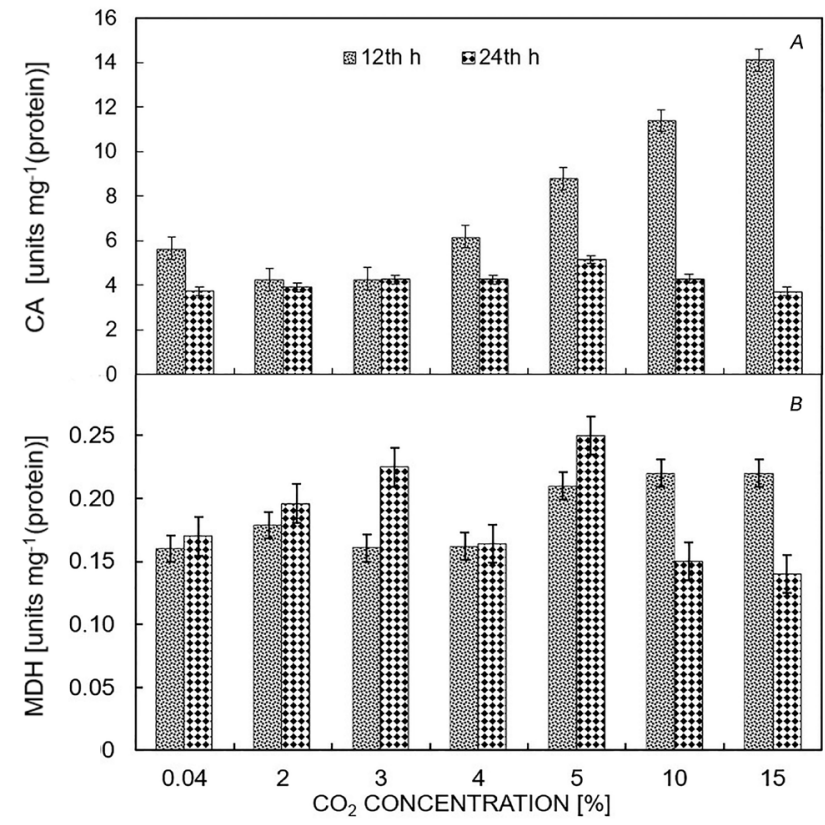

Fig. 4. Carbonic anhydrase (CA) $(A)$ and malate dehydrogenase (MDH) (B) activity in Phormidium valderianum BDU 20041 grown in ambient air and elevated $\mathrm{CO}_{2}$ concentration $(2,3,4,5$, 10 , and $\left.15 \% \mathrm{CO}_{2}\right)$ for 12 and $24 \mathrm{~h}$. Values are means $\pm \mathrm{SD}(n=3)$.

low at $15 \% \mathrm{CO}_{2}$ in $P$. valderianum BDU 20041. This was reflected in the NR and NIR activity, which decreased by 68 and $75 \%$ (Table 2) and probably caused reduced growth.

\section{Discussion}

Although a wealth of information is available on the structure, function, and activity of the major carbon-fixing enzymes, such as Rubisco and PEPC, the response of these enzymes to higher carbon concentrations is yet to be studied extensively (Sicher et al. 1994, Stöckel et al. 2013). Our study focused on the effect of different $\mathrm{CO}_{2}$ concentrations on some important carbon-fixing and nitrogen-metabolizing enzymes at varying time periods of P. valderianum BDU 20041 growth.

$P$. valderianum BDU 20041, when grown at various $\mathrm{CO}_{2}$ concentrations, was found to have optimum $\mathrm{CO}_{2}$ concentration of $3 \%$. There are many reports on improved cyanobacterial growth at higher $\mathrm{CO}_{2}$ concentrations (Mo-

Table 2. Activity of nitrogen assimilating enzymes of Phormidium valderianum BDU 20041 grown in ambient air $\left(0.04 \% \mathrm{CO}_{2}\right)$ and elevated $\mathrm{CO}_{2}$ concentration ( 3 and $15 \% \mathrm{CO}_{2}$ ) for 12 and $24 \mathrm{~h}$. Values (mean $\pm \mathrm{SD}, n=3$ ) with the same letters are not significantly different according to Tukey's HSD test $(p<0.05)$.

\begin{tabular}{|c|c|c|c|c|c|c|}
\hline \multirow[t]{2}{*}{$\mathrm{CO}_{2}[\%]$} & \multicolumn{2}{|c|}{$\begin{array}{l}\text { Nitrate reductase } \\
{\left[\mu \mathrm{g}(\text { nitrite formed }) \mathrm{g}^{-1}(\mathrm{DM}) \mathrm{min}^{-1}\right]}\end{array}$} & \multicolumn{2}{|c|}{$\begin{array}{l}\text { Nitrite reductase } \\
{\left[\mu \mathrm{g}(\text { nitrite removed }) \mathrm{g}^{-1}(\mathrm{DM}) \mathrm{min}^{-1}\right]}\end{array}$} & \multicolumn{2}{|c|}{$\begin{array}{l}\text { Glutamine synthetase } \\
{[\mathrm{mg}(\gamma \text {-glutamylhydroxamate formed })} \\
\left.\mathrm{g}^{-1}(\mathrm{DM}) \mathrm{min}^{-1}\right]\end{array}$} \\
\hline & $12 \mathrm{~h}$ & $24 \mathrm{~h}$ & $12 \mathrm{~h}$ & $24 \mathrm{~h}$ & $12 \mathrm{~h}$ & $24 \mathrm{~h}$ \\
\hline 0.04 & $3.308 \pm 0.123^{\mathrm{B}}$ & $3.787 \pm 0.099^{\mathrm{B}}$ & $3.260 \pm 0.114^{\mathrm{B}}$ & $3.625 \pm 0.213^{\mathrm{B}}$ & $3.557 \pm 0.113^{\mathrm{B}}$ & $4.073 \pm 0.217^{\mathrm{A}}$ \\
\hline 3 & $3.855 \pm 0.275^{\mathrm{A}}$ & $4.151 \pm 0.14 \mathrm{o}^{\mathrm{A}}$ & $3.526 \pm 0.058^{\mathrm{A}}$ & $4.352 \pm 0.281^{\mathrm{A}}$ & $4.021 \pm 0.226^{\mathrm{A}}$ & $4.541 \pm 0.183^{\mathrm{A}}$ \\
\hline 15 & $2.972 \pm 0.236^{\mathrm{C}}$ & $1.174 \pm 0.294^{\mathrm{C}}$ & $2.987 \pm 0.154^{\mathrm{C}}$ & $1.015 \pm 0.069^{\mathrm{C}}$ & $2.932 \pm 0.307^{\mathrm{C}}$ & $1.929 \pm 0.077^{\mathrm{B}}$ \\
\hline
\end{tabular}


roney and Somanchi 1999, Tang et al. 2011). Aphanothece microscopica Nägeli grew without any inhibition at a higher $\mathrm{CO}_{2}$ concentration of 2-20\% (Jacob-Lopes and Franco 2013). However, concentrations of $5 \%$ or more harmed the growth of Chlorella sp. (Chiu et al. 2008). This study aimed to look into the underlying physiological process that promotes growth at elevated $\mathrm{CO}_{2}$.

Radiometric assay of Rubisco showed higher enzyme activity at $3 \%$ which leads to the conclusion that $\mathrm{CO}_{2}$ concentration up to a certain level enhanced the activity of the primary carbon-fixing enzyme Rubisco in the Oscillatorian cyanobacterial form of $P$. valderianum $\mathrm{BDU}$ 20041. Through a variety of approaches (Friedberg et al. 1989, Pierce et al. 1989, Price and Badger 1989) it has been demonstrated that Rubisco and carbonic anhydrase localization in the carboxysomes is essential for the $\mathrm{CO}_{2}$ concentrating mechanism in cyanobacteria. Cultures grown at $15 \% \mathrm{CO}_{2}$ showed a lower activity than the cultures that received ambient $\mathrm{CO}_{2}$ (Fig. 2A). This result was similar to the pattern observed by Sicher et al. (1994) in tobacco plants grown under elevated $\mathrm{CO}_{2}$, which showed lower Rubisco activity to ambient air-grown cultures. This result was also concurrent with the finding of Stöckel et al. (2013), where lower levels of transcripts associated with $\mathrm{CO}_{2}$ and bicarbonate uptake were recorded. In another study, the Rubisco activity of the Chroococcidiopsis sp. strain TS-821 increased at 5\% $\mathrm{CO}_{2}$ but decreased at 10,15, and $20 \% \mathrm{CO}_{2}$, agreed with our finding (Hayashi et al. 1995).

At high concentrations of $\mathrm{CO}_{2}(6 \%)$, Rubisco biosynthesis in Rhodobacter sphaeroides, a non-sulfur photosynthetic bacterium, was found to be lower (Jouanneau and Tabita 1987). The number of carboxysomes and the Rubisco activity increased in Synechococcus PCC7942 cells when transferred to extremely low $\mathrm{CO}_{2}$ concentrations; however, the effect of higher extracellular $\mathrm{CO}_{2}$ concentration on the activity of Rubisco has not been examined (Harano et al. 2003). Cheng and Fuchigami (2000) have recorded higher Rubisco activity with increasing nitrogen availability. The above finding and the results from this study makes us hypothesize that the increasing $\mathrm{CO}_{2}$ in the medium causes cells starving for nitrogen and hence it results in reduced Rubisco activity. The Western blot of $P$. valderianum BDU 20041 showed that increasing $\mathrm{CO}_{2}$ concentration had positive effect on the Rubisco content and it corroborated with our findings in radiometric determination of Rubisco activity. With the support of the radiometric and Western blot assays, our results revealed that both the Rubisco activity and its content were higher at the elevated $\mathrm{CO}_{2}$ concentration after a 12-h growth period. Thus, it is safe to infer that the variation in activity is probably because of the increased synthesis of Rubisco leading to higher activity.

Our recent in silico analysis of the protein sequences of the cyanobacterial PEPC revealed that cyanobacteria from the order Oscillatoriales and Nostocales showed the presence of $\mathrm{a} \mathrm{C}_{4}$ determinant serine residue at position 923 , which is similar to that of the $\mathrm{C}_{4}$ plant, which is replaced by glycine in lower orders. These higher cyanobacterial orders possess a conserved PEPC-activating serine residue at position 39 in the N-terminus that is required for phosphorylation, a very important characteristic feature of the $\mathrm{C}_{4}$ PEPC. Hence, this finding suggests the similarity of higher cyanobacterial PEPC to $\mathrm{C}_{4}$ isoforms of higher plants (Shylajanaciyar et al. 2015). $\mathrm{CO}_{2}$ fixation through PEPC in the selected organism $P$. valderianum BDU 20041 (Oscillatoriales) is thus justified. PEPC activity was proportional to the $\mathrm{CO}_{2}$ increase after $12 \mathrm{~h}$, however, the cyanobacterium showed lower PEPC activities at a higher $\mathrm{CO}_{2}$ concentration at the end of 24-h period (Fig. $2 \mathrm{~B}$ ). Our results are in agreement with the findings of Omoto et al. (2012), who demonstrated that at decreased $\mathrm{CO}_{2}$ concentrations, the PEPC activity was higher, and at higher $\mathrm{CO}_{2}$ concentrations, it is speculated to be down-regulated, similarly to Rubisco. The correlation of $\mathrm{CO}_{2}$ fixation rate with the activities of Rubisco and PEPC is fairly logical. Hudson et al. (1992) also recorded a similar correlation between the $\mathrm{CO}_{2}$ assimilation rate and the Rubisco activity.

The poor activities of these enzymes at the higher $\mathrm{CO}_{2}$ concentration could be the reason for stunted cyanobacterial growth at higher $\mathrm{CO}_{2}(>10 \%)$. In-depth studies to enhance enzyme activities at higher $\mathrm{CO}_{2}$ could be a major breakthrough for implementation of microalgal carbon capture and storage.

The enzyme CA is involved in the catalysis of the interconversion of $\mathrm{HCO}_{3}{ }^{-}$and $\mathrm{CO}_{2}$ in the periplasm space. The CA activity was increasing with $\mathrm{CO}_{2}$ concentration till $12 \mathrm{~h}$ but after $24 \mathrm{~h}$, the activity of CA decreased and was almost similar at all the concentrations. Our results corroborate the findings of Chen and Gao (2003) in a marine diatom Skeletonema costatum and of Sicher et al. (1994) in tobacco plants. In tobacco plants, the CA activity of high concentration $\mathrm{CO}_{2}$-grown cells was observed to be higher until day 4, after which the activity was lower than that of the ambient $\mathrm{CO}_{2}$-grown cells.

Jaiswal et al. (2005) found increasing CA activity in two cyanobacteria, Anabaena sp. (ARM 629) and Nostoc calcicola, which were transferred from a higher $\mathrm{CO}_{2}$ concentration (2-25\%) to ambient $\mathrm{CO}_{2}$ concentration. The cells grown with ambient air (low $C_{\mathrm{i}}$ cells) showed higher CA activity in comparison with the cells grown with 2-4\% $\mathrm{CO}_{2}$ (high $C_{\mathrm{i}}$ cells) (Shiraiwa and Miyachi 1985). Reports are scarce on the effects of transferring cultures from ambient to elevated $\mathrm{CO}_{2}$ concentrations on the $\mathrm{CA}$ activity of microalgae. The present investigation indicates that the CA activity decreased when the cells grown in a lower concentration of inorganic carbon were transferred to the high $C_{\mathrm{i}}$ condition (enhanced $\mathrm{CO}_{2}$ ). This is because of the continuous addition of carbonates into the medium, which nullifies the necessity for carbonic anhydrase to accumulate carbonates around the carboxysomes. $\mathrm{MDH}$ activity did not show a large difference between the different $\mathrm{CO}_{2}$ concentrations and the time intervals tested (Fig. 4B).

For the cyanobacterial growth, ammonia is the preferred source of nitrogen, as the different nitrogen compounds, which serve as nutrients, are first converted to ammonia intracellularly (Johnson et al. 2017). In cyanobacteria, nitrate reductases (NR) and nitrite reductases (NIR) are ferredoxin-dependent enzymes, which provide ammonium. 
The ammonium is then incorporated into 2-oxoglutarate carbon skeleton, which results in the synthesis of glutamate (Flores and Herroro 1994).

The reduced nitrogen assimilation might be another reason for the reduced growth of the organism at $15 \% \mathrm{CO}_{2}$. Fonseca et al. (1997) reported transient increases in the Nia transcript in leaves and, especially, in the roots of Plantago major during the first $4 \mathrm{~d}$ after the transfer to higher $\mathrm{CO}_{2}$ concentrations. A transient $50 \%$ increase in the NR activity in the shoots and a doubling of the NR activity in the roots accompanied this result. In our study, increasing $\mathrm{CO}_{2}$ concentration to $3 \%$ resulted in increased activity of the nitrogen-assimilating enzymes, while an increase to $15 \%$ retarded the activity of these enzymes. It is difficult to hypothesize the factor that decides the switch of the mechanism from stimulation to retardation. One possible reason is that, at elevated $\mathrm{CO}_{2}$ concentrations, the nitrate/nitrogen available for uptake gets reduced for reasons that are poorly understood (Geiger et al. 1999), thus lowering the assimilation rates. The changes in nitrogen assimilation at elevated $\mathrm{CO}_{2}$ have not yet been studied in detail. Knowledge of the regulation of nitrogen metabolism and its interaction with carbon metabolism and growth processes need to be evaluated further through elaborate investigations.

Conclusions: Hence, it can be concluded that the better growth of the marine cyanobacterium $P$. valderianum $\mathrm{BDU}$ 20041 at higher $\mathrm{CO}_{2}$ concentrations of up to $3 \%$ is because of the maximum activities of carbon-fixing and nitrogenassimilating enzymes. The activities of the enzymes at higher $\mathrm{CO}_{2}$ concentrations ( $>3 \%$ ) were diminished, thereby causing a reduction in the $\mathrm{CO}_{2}$ fixation rate and growth at elevated $\mathrm{CO}_{2}$ concentrations. Further studies need to focus on the reasons for decreased growth at higher $\mathrm{CO}_{2}$ concentrations.

\section{References}

Baker B.R., Bramhall R.R.: Irreversible enzyme inhibitors. 189. Inhibition of some dehydrogenases by derivatives of 4-hydroxyquinoline-2 and -3-carboxylic acids. - J. Med. Chem. 15: 230-233, 1972.

Barcelos e Ramos J., Biswas H., Schulz K.G. et al.: Effect of rising atmospheric carbon dioxide on the marine nitrogen fixer Trichodesmium. - Global Biogeochem. Cy. 21: doi: 10.1029/2006GB002898, 2007.

Burkhardt S., Amoroso G., Riebesell U., Sültemeyer, D.: $\mathrm{CO}_{2}$ and $\mathrm{HCO}_{3}{ }^{-}$uptake in marine diatoms acclimated to different $\mathrm{CO}_{2}$ concentrations. - Limnol. Oceanogr. 46: 1378-1391, 2001.

Chen X., Gao K.: Effect of $\mathrm{CO}_{2}$ concentrations on the activity of photosynthetic $\mathrm{CO}_{2}$ fixation and extracellular carbonic anhydrase in the marine diatom Skeletonema costatum. Chinese Sci. Bull. 48: 2616-2620, 2003.

Cheng L., Fuchigami L.H.: Rubisco activation state decreases with increasing nitrogen content in apple leaves. - J. Exp. Bot. 51: 1687-1694, 2000.

Chiu S.-Y., Kao C.-Y., Chen C.-H. et al.: Reduction of $\mathrm{CO}_{2}$ by a high-density culture of Chlorella sp. in a semicontinuous photobioreactor. - Bioresource Technol. 99: 3389-3396, 2008.

de Morais M.G., Costa J.A.V.: Isolation and selection of microalgae from coal fired thermoelectric power plant for biofixation of carbon dioxide. - Energ. Convers. Manage. 48: 2169-2173, 2007.

Flores E., Herrero A.: Assimilatory nitrogen metabolism and its regulation. - In: Bryant D.A. (ed.): The Molecular Biology of Cyanobacteria. Pp. 487-517. Kluwer Academic Publishers, Dordrecht, 1994.

Fonseca F., Bowsher C.G., Stulen I.: Impact of elevated atmospheric $\mathrm{CO}_{2}$ on nitrate reductase transcription and activity in leaves and roots of Plantago major. - Physiol. Plantarum 100: 940-948, 1997.

Friedberg D., Kaplan A., Ariel R. et al.: The 5'-flanking region of the gene encoding the large subunit of ribulose-1,5bisphosphate carboxylase/oxygenase is crucial for growth of the cyanobacterium Synechococcus sp. strain PCC 7942 at the level of $\mathrm{CO}_{2}$ in air. - J. Bacteriol. 171: 6069-6076, 1989.

Fu F.X., Warner M.E., Zhang Y. et al.: Effects of increased temperature and $\mathrm{CO}_{2}$ on photosynthesis, growth, and elemental ratios in marine Synechococcus and Prochlorococcus (Cyanobacteria). - J. Phycol. 43: 485-496, 2007.

Geiger M., Haake V., Ludewig F. et al.: The nitrate and ammonium nitrate supply have a major influence on the response of photosynthesis, carbon metabolism, nitrogen metabolism and growth to elevated carbon dioxide in tobacco. - Plant Cell Environ. 22: 1177-1199, 1999.

Harano K., Ishida H., Kittaka R. et al.: Regulation of the expression of ribulose-1,5-bisphosphate carboxylase/oxygenase (EC 4.1.1.39) in a cyanobacterium, Synechococcus PCC7942.Photosynth. Res. 78: 59-65, 2003.

Hayashi N.R., Ishida T., Peerapornpisal Y. et al.: Effect of carbon dioxide concentration on the growth and RuBisCO activity of a thermophilic cyanobacterium, Chroococcidiopsis sp. strain TS-821. - J. Ferment. Bioeng. 80: 507-509, 1995.

Herrero A., Guerrero M.G.: Regulation of nitrite reductase in the cyanobacterium Anacystis nidulans. - Microbiology+ 132: 2463-2468, 1986.

Hudson G.S., Evans J.R., von Caemmerer S. et al.: Reduction of ribulose-1,5-bisphosphate carboxylase/oxygenase content by antisense RNA reduces photosynthesis in transgenic tobacco plants. - Plant Physiol. 98: 294-302, 1992.

Hutchins D.A., Fu F. X., Zhang Y. et al.: (2007) $\mathrm{CO}_{2}$ control of Trichodesmium N2 fixation, photosynthesis, growth rates, and elemental ratios: implications for past, present, and future ocean biogeochemistry. - Limnol Oceanogr. 52:1293-1304, 2007.

Jacob-Lopes E., Franco T.T.: From oil refinery to microalgal biorefinery. - J. $\mathrm{CO}_{2}$ Util. 2: 1-7, 2013.

Jaiswal P., Prasanna R., Kashyap A.K.: Modulation of carbonic anhydrase activity in two nitrogen fixing cyanobacteria, Nostoc calcicola and Anabaena sp. - J. Plant Physiol. 162: 1087-1094, 2005.

Johnson T.J., Jahandideh A., Isaac I.C. et al.: Determining the optimal nitrogen source for large-scale cultivation of filamentous cyanobacteria. - J. Appl. Phycol. 29: 1-13, 2017.

Jouanneau Y., Tabita F.R.: In vivo regulation of form I ribulose 1,5-bisphosphate carboxylase/oxygenase from Rhodopseudomonas sphaeroides. - Arch. Biochem. Biophys. 254: 290-303, 1987.

Kranz S.A., Levitan O., Richter, K.-U. et al.: Combined effects of $\mathrm{CO}_{2}$ and light on the $\mathrm{N}_{2}$-fixing cyanobacterium Trichodesmium IMS101: Physiological responses. - Plant Physiol. 154: 334-345, 2010.

Levitan O., Rosenberg G., Šetlík I. et al.: Elevated $\mathrm{CO}_{2}$ enhances nitrogen fixation and growth in the marine cyanobacterium Trichodesmium. - Glob. Change Biol. 13: 531-538, 2007.

Lowry O.H., Rosebrough N.J., Farr A.L., Randall R.J.: Protein measurement with the Folin phenol reagent. - J. Biol. Chem. 
193: 265-275, 1951.

Moroney J., Somanchi A.: How do algae concentrate $\mathrm{CO}_{2}$ to increase the efficiency of photosynthetic carbon fixation? Plant Physiol. 119: 9-16, 1999.

NOAA, Earth System Research Laboratory. http://www.esrl. noaa.gov/gmd/ccgg/trends/, 2018.

Omoto E., Taniguchi M., Miyake H.: Adaptation responses in C4 photosynthesis of maize under salinity. - J. Plant Physiol. 169: 469-477, 2012.

Owttrim G.W., Colman B.: Purification and characterization of phosphoenolpyruvate carboxylase from a cyanobacterium. J. Bacteriol. 168: 207-212, 1986.

Perchorowicz J.T., Raynes D.A., Jensen R.G.: Light limitation of photosynthesis and activation of ribulose bisphosphate carboxylase in wheat seedlings. - P. Natl. Acad. Sci. USA 78: 2985-2989, 1981.

Pierce J., Carlson T.J., Williams J.G.A.: Cyanobacterial mutant requiring the expression of ribulose bisphosphate carboxylase from a photosynthetic anaerobe. - P. Natl. Acad. Sci. USA 86: 5753-5757, 1989.

Price G.D., Badger M.R.: Expression of human carbonic anhydrase in the cyanobacterium Synechococcus PCC7942 creates a high $\mathrm{CO}_{2}$-requiring phenotype: evidence for a central role for carboxysomes in the $\mathrm{CO}_{2}$ concentrating mechanism. Plant Physiol. 91: 505-513, 1989.

Raven J.A.: The role of marine biota in the evolution of terrestrial biota: gases and genes. - Biogeochemistry 39: 139-164, 1997.

Rippka R., Deruelles J., Waterbury J.B. et al.: Generic assignments, strain histories and properties of pure cultures of Cyanobacteria. - Microbiology 111: 1-61, 1979.
Shapiro B.M., Stadtman E.R.: Glutamine synthetase (Escherichia coli). - In: Tabor H., White Tabor C.: Methods in Enzymology. Metabolism of Amino Acids and Amines. Part A. Pp. 910-922. Elsevier, 1970.

Shiraiwa Y., Miyachi S.: Role of carbonic anhydrase in photosynthesis of blue-green alga (cyanobacterium) Anabaena variabilis ATCC 29413. - Plant Cell Physiol. 26: 109-116, 1985.

Shylajanaciyar M., Dineshbabu G., Rajalakshmi R. et al.: Analysis and elucidation of phosphoenolpyruvate carboxylase in cyanobacteria. - Protein J. 34: 73-81, 2015.

Sicher R.C., Kremer D.F., Rodermel S.R.: Photosynthetic acclimation to elevated $\mathrm{CO}_{2}$ occurs in transformed tobacco with decreased ribulose-1,5-bisphosphate carboxylase/oxygenase content. - Plant Physiol. 104: 409-415, 1994.

Stöckel J., Elvitigala T.R., Liberton M., Pakrasi H.B.: Carbon availability affects diurnally controlled processes and cell morphology of Cyanothece 51142. - PLoS ONE 8: e56887, 2013.

Tang D., Han W., Li P. et al.: $\mathrm{CO}_{2}$ biofixation and fatty acid composition of Scenedesmus obliquus and Chlorella pyrenoidosa in response to different $\mathrm{CO}_{2}$ levels. - Bioresource Technol. 102: 3071-3076, 2011.

Tortell P.D.: Evolutionary and ecological perspectives on carbon acquisition in phytoplankton. - Limnol. Oceanogr. 45: 744-750, 2000.

Wilbur K.M., Anderson N.G.: Electrometric and colorimetric determination of carbonic anhydrase. - J. Biol. Chem. 176: 147-154, 1948.

(C) The authors. This is an open access article distributed under the terms of the Creative Commons BY-NC-ND Licence. 